\title{
Update to the status of Lindeni tetraphylla (Vander Linden, 1825) (Odonata Gomphidae) in Italy, with special reference to the Molise region
}

\author{
Andrea Corso ${ }^{*}$, Ottavio Janni ${ }^{2}$, Lorenzo De Lisio ${ }^{3} \&$ Carlo Fracasso ${ }^{4}$ \\ ${ }^{1}$ Via Camastra 10, 96100 Siracusa, Italy; e-mail: zoologywp@gmail.com \\ ${ }^{2}$ Via G.G. D’Amore 21, 81016 Piedimonte Matese, Caserta, Italy; email: coeligena@hotmail.com \\ 3Piazza V. Cuoco 2, 86100 Campobasso, Italy; e-mail: lorenzodelisio@gmail.com \\ ${ }^{4}$ Via di Sopra 19, 86018 Toro, Campobasso, Italy \\ ${ }^{*}$ Corresponding author
}

\begin{abstract}
Data concerning a new reproductive population of Lindenia tetraphylla (Vander Linden, 1825 (Odonata Gomphidae), found by the authors in Molise, Central Italy, between 2012 and 2018, are here reported. The species was recorded in some artificial farm ponds of the inland agricultural area, where localized but conspicuous reproductive populations are annually found. A single sighting from 2017 is also reported from the Abruzzo region, where the species has never been recorded before. The data here discussed update the status for Italy and enlarge the known distribution area. All the sites where the species is found in Molise are listed and mapped, brief data concerning habitat used are also reported.
\end{abstract}

KEY WORDS Lindenia tetraphylla; Molise region; status update Italy; small farm ponds.

Received 20.01.2019; accepted 25.02.2019; published online 28.02.2019

\section{INTRODUCTION}

Lindenia tetraphylla (Vander Linden, 1825), synonym Lindenia inkiti Bartenef, 1929 (Odonata Gomphidae), is an Irano-Turanian species, its main range spreading over the Eremian region, going from Central Asia to Arabia (Dumont, 1991; Giles, 1998; Schröter, 2010a; Waterston, 1984; Waterston \& Pittaway, 1991; Skvortzov \& Snegovaya, 2014). It is distributed also from Western Pakistan to the Caucasus region, the Levant and Turkey (mostly southern Anatolia) to the Western Mediterranean (Schneider, 1981, 1988; Schneider \& Dumont, 1997, 2015; Schorr et al., 1998; Kalkman, 2006; Kalkman \& Van Pelt, 2006; Borisov \& Haritonov, 2008; Boudot et al., 2009; Schröter 2010a, 2010b; Boudot \& Kalkman, 2015). It was recently found in Bulgaria (Gastaron \& Beshkov, 2010), where it is expanding its distribution (Kolev \& Boudot, 2018), and Crete (Boudot et al., 2009, Boudot, 2014; Stille et al., 2014; Boudot \& Kalkman, 2015) and is now considered resident in the western Balkans and Greece (Boudot \& Kalkman, 2015; Lopau, 2010; Vilenica et al., 2016). It is a very mobile nomadic species (Fraser 1936; Schneider 1981). Adults are known to migrate over long distances from their reproductive locality (Boudot \& Kalkman, 2015). Many out of range records may be referred to vagrant specimens, but some isolated localities were proved to be inhabited for several consecutive years, demonstrating at least a temporary reproduction far from its core range (Boudot \& Kalkman, 2015). For example, the species has been recorded occasionally in the 
Maghreb: in particular, it was considered reproductive in Tunisia in summer 2000 and 2002 (Kunz \& Kunz, 2001; Boudot \& Kalkman, 2015), while in Algeria, where it was considered previously extinct (Samraoui \& Menaï, 1999, Samraoui \& Corbet, 2000; Boudot et al., 2009; Boudot \& Kalkman, 2015), it was rediscovered in 2014 with evidence of reproduction in one site (Hamzaoui et al., 2015). As there is no continuous monitoring for these North African countries, its present status is unknown. In Europe, this species occurs in the Mediterranean basin, where it is very localized (Kalkman et al., 2010; Boudot \& Kalkman, 2015).

The species is in fact listed as vulnerable in Annexes II and IV of the Habitats Directive (Kalkman et al., 2010). The type specimen is from Campania, Southern Italy, where no confirmed records were obtained in recent time. Elsewhere in Italy, the species was reported in the past during the mid 1800 to early 1900 (Sélys-Longchamps, 1843; Bentivoglio, 1910a,b, 1913), until recently (Utzeri, 2006; Riservato et al., 2014 ). In this note, we report data about a recently discovered Italian population, considered wealthy and rather relevant for the status of the species in Italy and Europe as well. After the first random discovery in 2012, when one male was photographed in Molise region (Central Italy), we yearly collected numerical and distributional data. In 2017, we observed a single specimen in Abruzzo region. The results are here briefly summarised.

\section{MATERIAL AND METHODS}

From 2012 to 2018 , we have mapped all the suitable sites, therefore having the right environmental characteristics, in the Molise region (Figs. $1,2)$. These sites consist of small-medium sized agricultural irrigation basins (Fig. 2). For each site considered, we annually performed at least two visits between June and August. Environmental characteristics, extension and GPS coordinates of all the sites where the species was found were noted. The coordinates were recorded using the UTM WGS84 $33 \mathrm{~N}$ reference system. Cartographic processing was done using QGIS 2.14 Essen. At each visit, the number of observed specimens, sex and age was noted when possible. Many of these specimens were captured with entomological nets for photo- graphic documentation but, given the rarity of the species, they were all subsequently released (Figs. 3-6). The specimen observed in Abruzzo was detected during a study on the dragonflies of the Majella National Park, conducted in 2017 (Corso \& Biscaccianti, ined.).

ABBREVIATIONS. AC: Andrea Corso; CF: Carlo Fracasso; ex/exx: specimen/specimens; max: maximum count; min: minimum count.

\section{RESULTS}

All the sites where the species has been found in Molise are shown in figure 2 and listed in Table 1. The first report for Molise refers to 1 mature male photographed on 16.VI.2012 by CF and determined by $\mathrm{AC}$, in the site called Montorio nei Frentani (CB) (498129, 4625799) (Table 1). A few days later, on 29.VI.2012, at the same site, we observed up to a maximum of 20-25 exx (16 males, 4 females) (Figs. 3-6). On 30.VI.12 on the site called Laghetto Iacoluto, Salcito (CB), 4 males and 1 female were observed (Table 1). Between 2013 and 2018, the observation sites rose to six, for a total of 205 exx observed (min-max: 13-57 exx), mostly males, with an average of 29.3 exx per year and 34.2 per site (Table 1). The most relevant site was always the first one we discovered, with 148 exx in total observed in the seven years of study and a range of 850 exx. (average of 21.2 exx/year) (Table 1). Here in 2016 and 2017 at least 20 exuviae have been found along the muddy banks of the irrigated artificial basin (AC). For Abruzzo, we obtained a single observation, referred to 1 male observed on 18.VII.2017 in the Piana del Sagittario, between Sulmona and Pratola Peligna (L'Aquila) (4264695, 13522446) (AC \& A. Pulvirenti, ined.). It is not clear, in the current state of knowledge, whether it was simply an erratic exemplar or if there is a small reproductive nucleus in the area that has so far escaped research.

Habitat characterized by arable crops with prevalence of cereal crops attributable to the land use category "arable land in non-irrigated areas" (CLC 211), within which there are artificial water basins created for irrigation purposes with an average size of about 150 square meters. In only one case (Sant'Angelo Limosano, Laghetto Cascapere) the lake is of natural origin. The distance from the 
sea is on average $20 \mathrm{~km}$ (min-max: $2.4-43.9 \mathrm{~km}$ ). In all cases, there is a dense vegetation along the banks, mainly Phragmites sp. and Typha latifolia (L.). The immediate vicinity is invariably wide cultivated fields with low and dense vegetation, flat or hilly, always very rich in numerous species of Or-

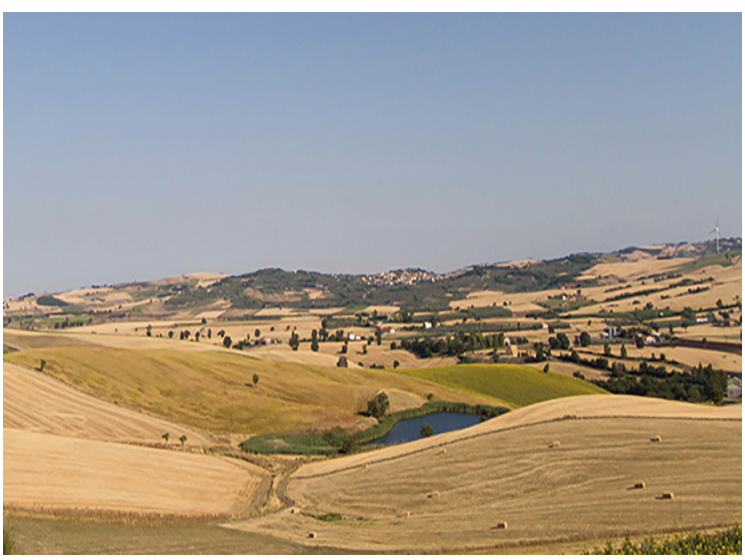

Figure 1. Typical habitat where Lindenia tetraphylla was found in Molise region, Central Italy. thoptera, one of the main prey of the species. The observation site of Abruzzo is a fluvial plain (Fiume Sagittario) with dense arboreal coverage, with numerous temporary flooded fields but with the presence of permanent scattered swampy areas with rich typhus and reed beds.

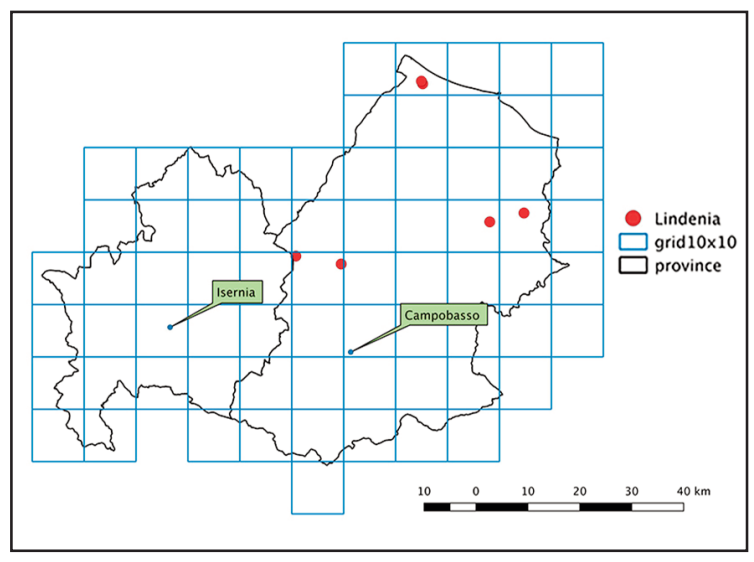

Figure 2. Lindenia tetraphylla in Molise region, Central Italy: in green are indicated the two provinces .

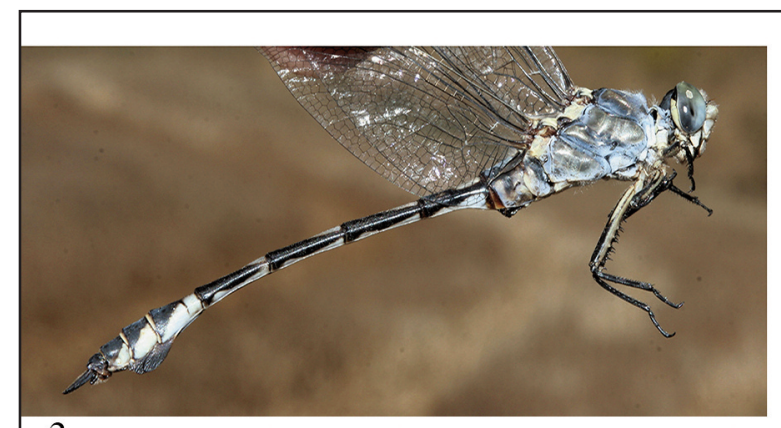

3
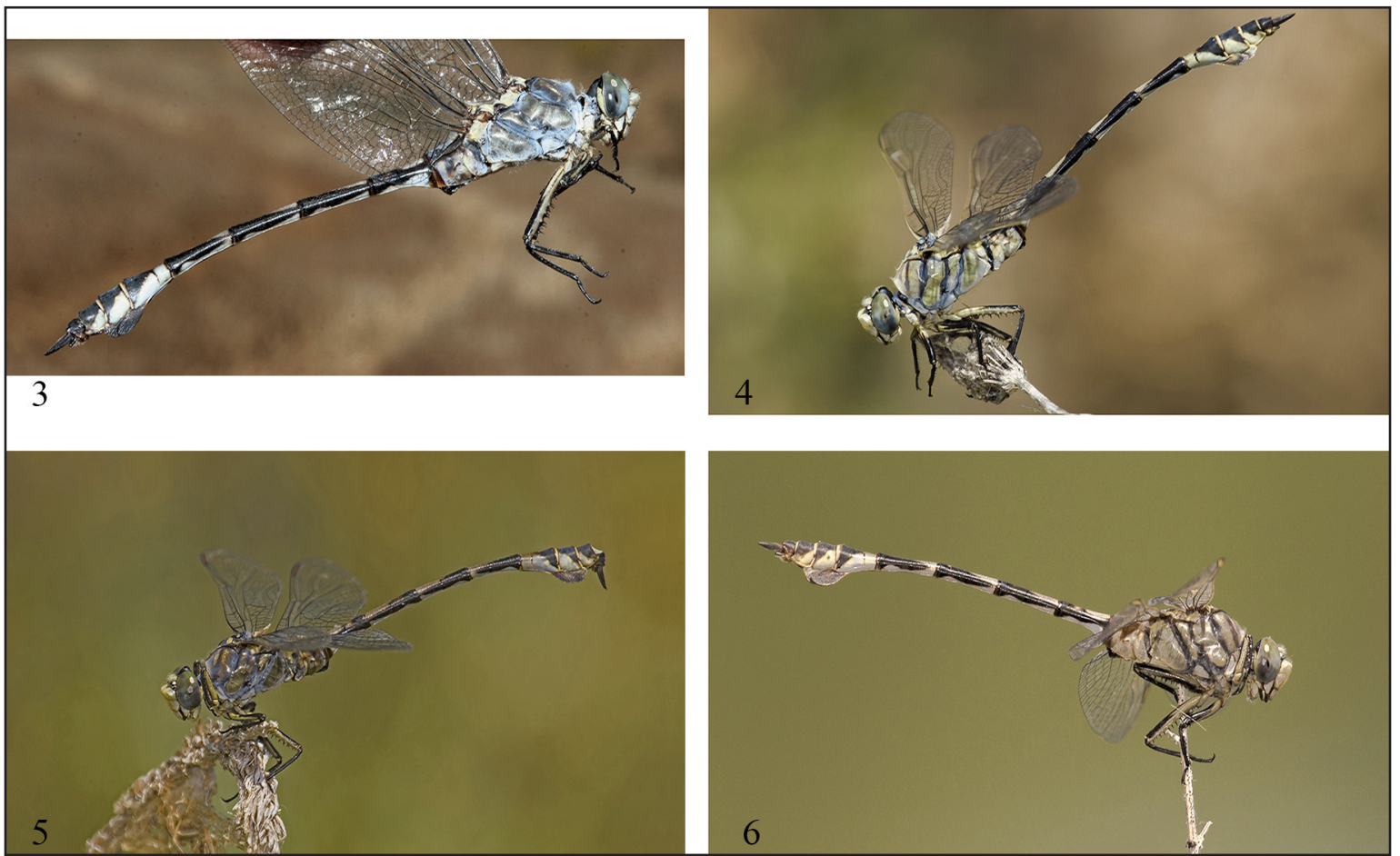

Figure 3. The first captured specimen of Lindenia tetraphylla from Molise region, Central Italy, 29.VI.2012 (photo A. Corso). Figures 4-6. Males of L. tetraphylla from Molise region, Central Italy (various date from 2013 to 2017) (photos C. Fracasso). 


\section{DISCUSSION}

Stable reproductive populations for Tuscany and Sardinia, referred to about 10 different areas, have been reported and were considered the only in Italy. For the other known areas to date (about 15 additional sites), only anecdotal observations are available, like for Campania, Umbria, Puglia (Galletti, 1978; Terzani, 2002; Utzeri et al., 2006; Hardersen \& Leo, 2011; Riservato et al., 2014). Even though there have been no confirmed recent observations for Campania and Lazio (Riservato et al., 2014; Janni \& Corso, ined.), in 2017 a new reproduction site was reported for Sicily (Surdo, 2017).

For Abruzzo, no previous records were known (Riservato et al., 2014). Therefore, our observation is currently the first for the region. Here, more careful and extensive future studies will have to clarify its status and real distribution. The sites considered to be of major national importance were all located in Tuscany, for example those of Lago Accesa and Lago della Rancia, with observations referable to a maximum of 20-30 exx, and secondarily in Sar- dinia (Utzeri, 2006; Hardersen \& Leo, 2011). From what is available in the literature, the Molise population we discovered in 2012 should today be the most consistent in Italy, and at the current state of knowledge probably among the most relevant in Central and Western Europe (Boudot \& Kalkman, 2015; Vilenica et al., 2016).

\section{CONCLUSIONS}

The species seems to be expanding its range: the increasing number of observation / reproduction stations discovered in Sardinia, Tuscany and Umbria, as well as from the new area in Sicily, in fact seem to indicate a positive trend (Hardersen \& Leo, 2011; Surdo, 2017). However, we do not know if these data reflect a real colonization of new areas, or more simply a greater coverage of the territory and a greater effort in odonatological research, which actually happened in the last decade in Italy. It is probable that the colonization of Molise took place through the arrival of erratic individuals of Balkan origin rather than from Tuscany, even if it

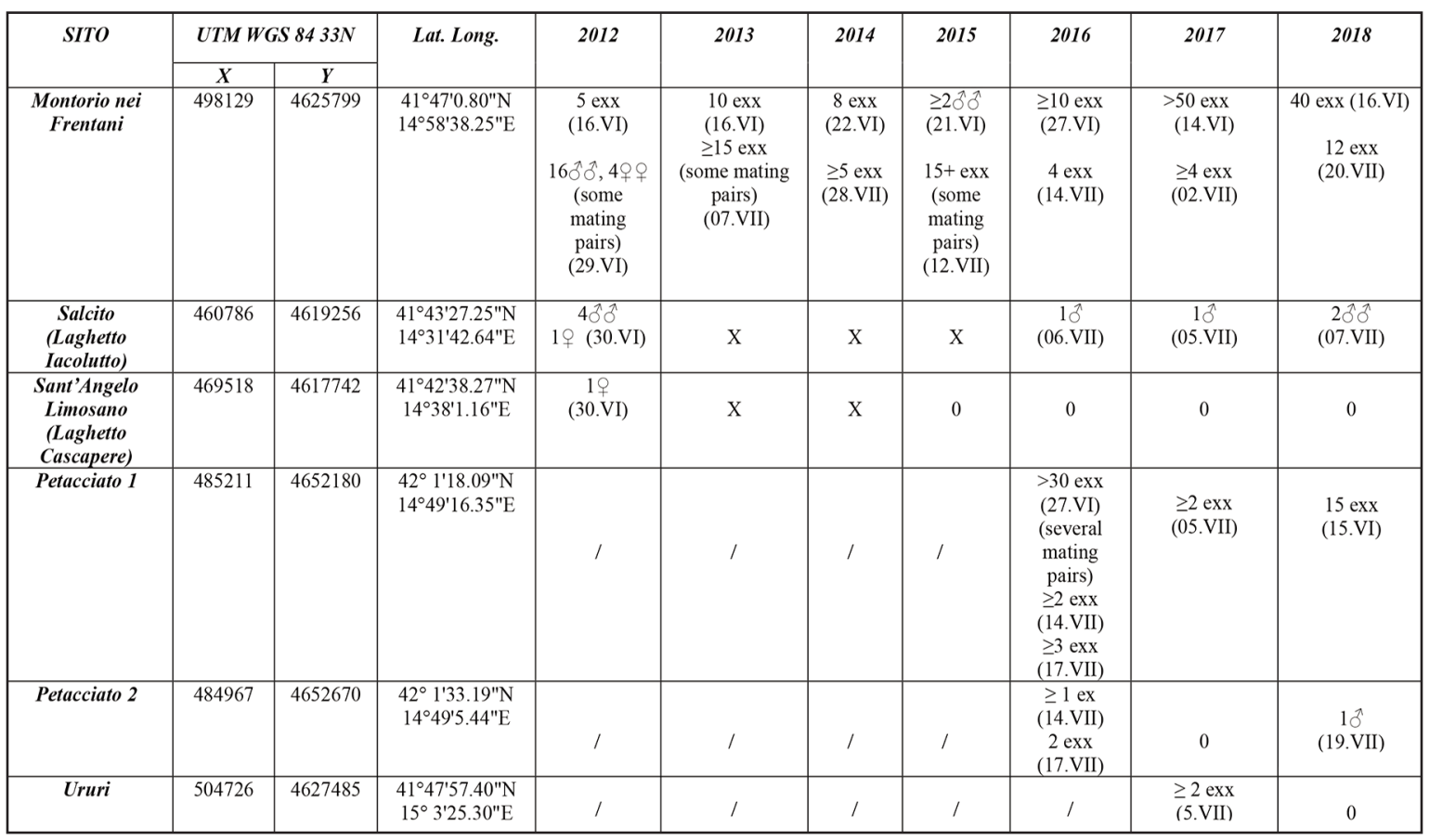

Table 1. Number of Lindenia tetraphylla observed per site in Molise region, central Italy, from 2012 to 2017. Site name and GPS coordinates are reported (both UTM WGS 84 33N X,Y that Latitude and Longitude), number of specimens (exx) per year (sex reported when noticed). The symbol X indicate that the site was not visited / site not known before (data lacking), 0 that no specimens were recorded. In brackets, date of observations and notes (as in mating pairs recorded). 
is not possible to establish with certainty the origin of the colonizers. Further future researches are necessary in order to extend the knowledge related to its distribution in Molise, Abruzzo, Umbria and Sicily, as well as on the actual presence or not in Lazio and Campania, in order to collect more extensive data on the actual consistency of the populations present in Italy. In addition, targeted research should also be carried out in Puglia, where the species is likely to be found but it is yet to be discovered, while in Sicily a larger portion of territory should be monitored.

\section{ACKNOWLEDGEMENTS}

We wish to thank Prof. Carlo Utzeri (Roma, Italy) for his help with references and useful suggestion. Verena Penna (Roma, Italy), Andrea Pulvirenti (Roma, Italy), Roberto Casalini (Roma, Italy), Mario Cappelli (Roma, Italy), Alessandro Biscaccianti (Roma, Italy) are thanked for their help in the field. The Majella National Park Authority (Abruzzo) and in particular Dr. Pino Marcantonio (Sulmona, Italy), is sincerely thanked for the funds for the research in their park as part of studies to monitor and protect dragonflies species in the Habitats Directive. The Leica Sport Optics is thanked (in particular Dr. Francesco Corrà and Nanette Roland) for providing the optical instruments used by A. Corso during this study.

\section{REFERENCES}

Bentivoglio T., 1910a. La Lindenia tetraphylla in Italia. Monitore zoologico italiano, 21: 309.

Bentivoglio T., 1910b. Cattura della Lindenia tetraphylla in Lucca. Atti della Società toscana di scienze naturali, Pisa, Processi verbali, 19: 59.

Bentivoglio T., 1913. Nuove osservazioni sulla Lindenia tetraphylla. Atti della Società toscana di scienze naturali, Pisa, Processi verbali, 22: 20.

Borisov S.N. \& Haritonov A.Y., 2008. The dragonflies (Odonata) of Middle Asia. Part 2 (Anisoptera). Euroasian Entomological Journal, 7: 97-123.

Boudot J.P., 2014. A brief observation of egg laying in Lindenia tetraphylla (Odonata: Gomphidae) on Kríti (Crete), Greece. Notulae odonatologicae, 8: 94-96.

Boudot J.P. \& Kalkman V. (Eds.), 2015. Atlas of the European dragonflies and damselflies. KNNV Publishing, The Netherlands, 384 pp.
Boudot J.P., Kalkman V.J., Azpilicueta Amorín M., Bogdanović T., Cordero Rivera A., Degabriele G., Dommanget J.L., Ferreira S., Garrigós B., Jović M., Kotarac M., Lopau W., Marinov M., Mihoković N., Riservato E., Samraoui B. \& Schneider W., 2009. Atlas of the Odonata of the Mediterranean and North Africa. Libellula, Supplement 9: 1-256.

Dumont H.J., 1991. Fauna palaestina. Insecta V. Odonata of the Levant. Israel Academy of Sciences and Humanities, Jerusalem, 297 pp.

Fraser F.C., 1936. The fauna of British India including Ceylon and Burma. Odonata. Volume 3. Taylor. \& Francis, London, 461 pp.

Galletti P.A., 1978. Nuovi reperti di Lindenia tetraphylla (V.L.) in Italia (Odonata, Gomphidae). Bollettino della Società entomologica italiana, 110: 223.

Gastaron V. \& Beshkov S., 2010. Lindenia tetraphylla (Vander Linden, 1825) (Odonata: Gomphidae) a new genus and species for the Bulgarian fauna. The entomologist's record and journal of variation, 122: 272274.

Giles G.B., 1998. An illustrated checklist of the damselflies and dragonflies of the United Arab Emirates. Tribulus, Bulletin of the Emirates Natural History Group, 8: 9-15.

Hamzaoui D., Hafiane M., Mebarki M., Arab A., Alfarhan A. H. \& Samraoui B., 2015. The Gomphidae of Algeria and the Maghreb: status, ecology and conservation (Insecta: Odonata). International Journal of Odonatology, 18: 1-17. https://doi.org/10.1080/ 13887890.2015 .1043655

Hardersen S. \& Leo P., 2011. Dragonflies of Iglesiente (SW Sardinia) and additional records of rare or poorly known species from Sardinia (Odonata). In: Nardi G., Whitmore D., Bardiani M., Birtele D., Mason F., Spada L. \& Cerretti P. (Eds.), Biodiversity of Marganai and Montimannu (Sardinia). Research in the framework of the ICP Forests network. Conservazione Habitat Invertebrati, 5: 243-253.

Kalkman V.J., 2006. Key to the dragonflies of Turkey, including species known from Greece, Bulgaria, Lebanon, Syria, the Trans-Caucasus and Iran. Brachytron, 10: 3-82.

Kalkman V.J. \& Van Pelt G.J., 2006. New records of rare or uncommon dragonflies in Turkey (Odonata). Brachytron, 10: 154-162.

Kalkman V.J., Boudot J.P., Bernard R., Conze K.J., De Knijf G., Dyatlova E., Ferreira S., Jović M., Ott J., Riservato E. \& Sahlén G., 2010. European Red List of Dragonflies. Luxembourg: Publications Office of the European Union.

Kolev N. \& Boudot J.P., 2018. Evidence of reproduction of Lindenia tetraphylla in Bulgaria (Odonata: Gomphidae). Notulae odonatologicae 9: 11-17. https:// doi.org/10.5281/zenodo.1230417 
Kunz B. \& Kunz D., 2001. Lindenia tetraphylla: Wiederfund für Nordafrika (Odonata: Gomphidae). Libellula, 20: 79-85.

Lopau W., 2010. Verbreitungsatlas der Libellen in Griechenland (Odonata). Libellula, Supplement 10: 51-53.

Riservato E., Festi A., Fabbri R., Grieco C., Hardersen S., La Porta G., Landi F., Siesa M.E. \& Utzeri C., 2014. Odonata. Atlante delle libellule italiane - Preliminare. Società Italiana per lo Studio e la Conservazione delle Libellule. Collana "le Scienze" (17), Edizioni Belvedere, Latina, $224 \mathrm{pp}$.

Samraoui B. \& Corbet P., 2000. The Odonata of Numidia, northeastern Algeria. Part I: status and distribution. International Journal of Odonatology, 3: $11-25$.

Samraoui B. \& Menaï R., 1999. A contribution to the study of Algerian Odonata. International Journal of Odonatology, 2: 145-165.

Schneider W., 1981. Eine Massenwanderung von Selysiothemis nigra (Vander Linden, 1825) (Odonata: Macrodiplactidae) und Lindenia tetraphylla (Vander Linden, 1825) (Odonata: Gomphidae) in Südjordanien. Entomologische Zeitschrift, 91: 97-102.

Schneider W., 1988. Dragonflies (Odonata) of the Wahiba Sands and adjacent Areas, Eastern Oman. Journal of Oman Studies Special Report, 3: 377388.

Schneider W. \& Dumont H.J., 1997. The dragonflies and damselflies (Insecta: Odonata) of Oman. An updated and annotated checklist. Fauna of Saudi Arabia, 16: 89-110.

Schneider T. \& Dumont H.J., 2015. Odonata records from southern Iran. Notulae odonatologicae, 8: 117 155.

Sélys-Longchamps E., 1843. Notes sur quelques Odonates d'Europe. Annales de la Société entomologique de France, Paris, (2) 1: 107-109.

Schorr M., Schneider W. \& Dumont H.J., 1998. Ecology and distribution of Lindenia tetraphylla (Insecta, Odonata, Gomphidae): a review. International Journal of Odonatology, 1: 65-88.

Schorr M., Schneider W. \& Dumont H.J., 1998. Ecology and distribution of Lindenia tetraphylla (Insecta,
Odonata, Gomphidae): a review. International Journal of Odonatology, 1: 65-68.

Schröter A., 2010a. The Odonata of Kyrgyzstan, part I Critical national checklist, annotated list of records and collected data of the summer half-years 2008 and 2009. International Dragonfly Fund, 28: 1-72.

Schröter A., 2010b. On a collection of dragonflies from eastern Georgia, with the first record of Sympetrum arenicolor (Odonata: Libellulidae). Libellula, 29: 209-222.

Skvortsov V.E. \& Snegovaya N.Y., 2014. Additions to the knowledge of the Odonata fauna of Azerbaijan, with six new records. Notulae odonatologicae, 8: 67-76.

Stille M., Stille B. \& Schröter A., 2014. Lindenia tetraphylla, new for the island of Kérkira (Corfu), Greece (Odonata: Gomphidae). Notulae odonatologicae, 8: 77-116.

Surdo S., 2017. First record of Lindenia tetraphylla (Vander Linden, 1825) and rediscovery of Orthetrum nitidinerve (Selys, 1841) in Sicily (Insecta Odonata). Fragmenta Entomologica, 49: 1-5. https://doi.org/10. 4081/fe.2017.263

Terzani F., 2002. Ricerche odonatologiche in Toscana. 8. La Lindenia tetraphylla (Van der Linden, 1825). Quaderno di Studi e Notizie di Storia Naturale della Romagna, 16 (suppl.): 5.

Waterston A.R., 1984. Insects of Southern Arabia. Odonata from the Yemens and Saudi Arabia. Fauna of Saudi Arabia, 6: 451-472.

Waterston A.R. \& Pittaway A.R., 1991. The Odonata or Dragonflies of Oman and neighbouring territories. Journal of Oman Studies, 10: 131-168.

Utzeri C., Belfiore C. \& Peels F., 2006. Some new records of Lindenia tetraphylla (Vander Linden) in Italy (Anisoptera: Gomphidae). Notulae odonatologicae, 6: 90.

Vilenica M., Alegro A., Koletić N. \& Mihaljević Z., 2016. New evidence of Lindenia tetraphylla (Vander Linden, 1825) (Odonata, Gomphidae) reproduction at the North-Western border of its distribution. Natura Croatica, 25: 287-294. https://doi.org/10.20302/NC. 2016.25.24 